\title{
Developments
}

\section{Article 50 and Member State Sovereignty}

\author{
By Dennis Dixon*
}

\begin{abstract}
Article 50 of the Treaty on European Union was originally viewed by national constitutional courts as an important provision for upholding state sovereignty. The German Constitutional Court emphasized the provision in its reconciliation of the Lisbon Treaty with state sovereignty. The Czech and Latvian Constitutional Courts saw Article 50 as creating a balanced process for the exercise of the sovereign right to withdraw from the European Union. Prior to the Brexit referendum, there was little doubt in the literature that an Article 50 agreement could address the entirety of the future relationship between a withdrawing member state and the European Union. Since the Brexit referendum, the European Union has taken an increasingly narrow view of Article 50. This, combined with interpretations of other Treaty provisions, have both created significant disadvantages to the withdrawing member state. If-above and beyond natural imbalances in bargaining power-EU Law creates a position of inequality between the withdrawing member state and the EU in negotiations, then the pooled-sovereignty model of the European Union is called into doubt. Article 50 cannot simultaneously be viewed as upholding state sovereignty, whilst being exit-hostile to any state that uses the provision.
\end{abstract}

\footnotetext{
* The author is a tutor at the Institute of Law, Jersey, and a legal adviser for the Law Officers of that Island. He holds a doctorate in constitutional law from the University of London. He would like to thank the anonymous reviewer for the very useful comments. All views are his own, and not those of his employers.
} 


\section{A. Premise}

This article argues that Article 50 of the Treaty on European Union has had two lives, pre and post June 23, 2016. To use Stijn Smismans' categorization, there have been exitfriendly interpretations rooted in the idea of Article 50 as "confirmation of a unilateral right of a Member State to withdraw," and exit-hostile interpretations, which create "a hostile rather than friendly environment for withdrawal." ${ }^{1}$ Before the referendum, the former type of interpretations prevailed, but, afterwards, the withdrawal process has been read in ways that significantly disadvantage the withdrawing member state. If -as one writer said-giving the right to leave had a strong symbolic content, ${ }^{2}$ then there is also a strong practical and symbolic significance if Article 50 simultaneously gives that right, but treats its own use with hostility.

The first-and principal-contention in this contribution is that the interpretation of Article 50 reached by the European Union since the United Kingdom referendum has changed significantly from pre-existing literature. When Falvier and Platon said in August 2016 that there was a common assumption that Article 50 was limited to divorce matters, ${ }^{3}$ it was not an assumption greatly supported by pre-referendum literature, which tended to assume that negotiations would address all matters from settling accounts to the future relationship. Other matters have also come sharply into view in the post-referendum era, for example, possible limits on the right of a withdrawing member state to make preparations for its trade relationship with third countries. The result is a very different picture of the Article 50 process than that found in the pre-referendum literature.

The second contention is that this shift has been to the disadvantage of the withdrawing member state. There have been assertions as to: (a) What can be agreed in the Article 50 processes (e.g. "[f]irst you exit then you negotiate" ${ }^{4}$ ); (b) what the withdrawing member state cannot legally do to prepare for exit (e.g. negotiate arrangements with third countries); (c) which financial obligations outlast membership; and (d) the required sequencing of negotiations to prioritize certain issues. These either exclusively or disproportionately work against the withdrawing member state.

\footnotetext{
${ }^{1}$ Stijn Smismans, About the Revocability of Withdrawal: Why the EU (Law) Interpretation of Article 50 Matters, U.K. CONST. L. BLOG (Nov. 29, 2016), https://ukconstitutionallaw.org/2016/11/29/stijn-smismans-about-therevocability-of-withdrawal-why-the-eu-law-interpretation-of-article-50-matters/.

${ }^{2}$ Ricardo Alonso García, The Spanish Constitution and the European Constitution: The Script for a Virtual Collision and Other Observations on the Principle of Primacy, 6 GERMAN L.J. 1001, 1020 (2005).

3 Hugo Flavier \& Sébastien Platon, Brexit: A Tale of Two Agreements, EUR. L. BLOG (Aug. 20, 2016), http://europeanlawblog.eu/2016/08/30/brexit-a-tale-of-two-agreements/.

${ }^{4}$ Mark Urban, EU Trade Commissioner: No Trade Talks Until Full Brexit, BBC ONLINE (June 30, 2017), http://www.bbc.co.uk/news/uk-politics-eu-referendum-36678222.
} 
The third contention is more theoretical and more difficult. It will be argued that the new readings of Article 50 are inconsistent with the idea of member state sovereignty being a core value of the European Union. Drawing from the Canadian Supreme Court's analysis of how-in a union built on values of federalism, democracy, and the rule of law-secession negotiations should be conducted with equal respect for two legitimate majorities, ${ }^{5}$ it will be argued that Article 50 is now creating a hostile environment for those leaving the European Union. ${ }^{6}$ The extent to which Article 50 can be seen as supporting member state sovereignty is thus diminished. A withdrawing member state cannot complain about the natural vicissitudes of secession-such as asymmetries in bargaining power ${ }^{7}-b_{\text {but }}$ a process that structurally adds to those vicissitudes cannot be said without qualification to uphold state sovereignty.

\section{B. The Text of Article $\mathbf{5 0}$}

It is inevitable to start with the text of Article 50, and to highlight the interpretative choices that have emerged. The provision governs the process of withdrawal in terms of time scale, the European Union's own decision-making, and what is to be negotiated. It is useful to set out at this stage the construction put forward by the European Union in its negotiating documents, although the wider literature on the provision will be considered later. The purpose of this section is instead to deal with the bare bones of the text and summarize the interpretative choices of what has proved to be a poorly drafted provision.

\section{Article 50(2)}

The key provision on the terms of exit and future relationship is Article 50(2):

A Member State which decides to withdraw shall notify the European Council of its intention. In the light of the guidelines provided by the European Council, the Union shall negotiate and conclude an agreement with that State, setting out the arrangements for its withdrawal, taking account of the framework for its future relationship with the Union. That agreement shall be negotiated in accordance with Article 218(3) of the Treaty on the Functioning of the European Union. It shall be concluded on behalf of the Union by the Council, acting by a qualified majority, after obtaining

\footnotetext{
${ }^{5}$ See Secession of Quebec, [1998] 2 S.C.R. 217, paras. 66, 93, 152 (Can.).

${ }^{6}$ Smismans, supra note 1.

${ }^{7}$ Takis Tridimas, Article 50: An Endgame Without an End?, 27 KINGS L.J. 297, 313 (2016).
} 
the consent of the European Parliament. (Emphasis added).

The approach taken by the European Union is set out in a European Council Recommendation for a Decision and European Council Guidelines. ${ }^{8}$ The Explanatory Note to that European Council Decision affirms that: "Negotiations with the United Kingdom will be conducted as a single package. In accordance with the principle that nothing is agreed until everything is agreed, individual items cannot be settled separately." (Emphasis added).

Despite being a single package, we find that the negotiations will have two phases: The "divorce/withdrawal agreement phase" and the "framework phase," and whilst part of a single arrangement, they are otherwise quite separate. ${ }^{9}$

The recommended negotiating directives in Annex cover the first phase of the negotiations, which will prioritise matters which, at this stage, have been identified as strictly necessary to ensure an orderly withdrawal. ...

An agreement on a future relationship between the Union and the United Kingdom can only be finalised and concluded once the United Kingdom has become a third country. However, Article 50 of the Treaty on European Union requires that the framework for the future relationship with the Union is taken into account in the agreement setting out the arrangements for the withdrawal. To this end, as soon as the European Council decides that sufficient progress has been achieved to allow negotiations to proceed to the next phase, an overall understanding with the United Kingdom on the framework for the future relationship should be identified during the second phase of the negotiations under Article 50. (Emphasis added).

\footnotetext{
${ }^{8}$ Recommendation for a Council Decision Authorising the Commission to Open Negotiations on an Agreement With the United Kingdom of Great Britain and Northern Ireland Setting out the Arrangements for its Withdrawal from the European Union, COM (2017) 218 final (May 5, 2017) (hereinafter "Council Decision"); and Special Meeting of the European Council (Art. 50) (29 April 2017) - Guidelines, EUCO XT 20004/17 (Apr. 29, 2017) (hereinafter "Council Guidelines").
}

${ }^{9}$ Council Decision, supra note 8, at Explanatory Note; and Council Guidelines, supra note 8, at para. 5. 
On this view, there is thus a divorce/future relationship divide, and only the former can be agreed conclusively. A future framework is not even the second order of business, but at best something that may cast a shadow on how divorce issues are resolved: "[N]egotiations will not address matters relating to the framework for the future relationship between the EU and the United Kingdom, except by taking into account that framework in the negotiations." 10

This dichotomy between the divorce and the future is mitigated by the possibility of transitional arrangements - a concept not obvious on the face of Article 50. The reasoning is set out clearest in the European Parliament's resolution on negotiations. Article 50 does not extend to agreeing future relationships-which may only take place when the withdrawing member state becomes a third country-but transitional arrangements can be made anticipating what would be expected on the basis of the future framework. This division also provides a foundation in Article 50 for the insistence on sequencing of discussions: The core business is the divorce, so that must be agreed first. ${ }^{11}$ As the framework will not be negotiated, the transition requires "identification of an understanding over the framework for the future relationship."12

There is nothing in Article 50 that compels this interpretation. It is important to look again at the key phrase from Article 50, whose broadly worded concepts have been interpreted as creating an intricate regime of what can and cannot be done, and the sequence to be observed: "[T]he Union shall negotiate and conclude an agreement with that State, setting out the arrangements for its withdrawal, taking account of the framework for its future relationship with the Union. ..."

If transitional arrangements must anticipate future specific agreements and are an integral and legitimate part of the Article 50(2) agreement, it is unclear why transitional arrangements should have a lower priority to pure divorce issues in a sequencing reached on the basis of Article 50(2)'s requirements. This is particularly the case given that such arrangements are not even mentioned in the provision, but must fall within the generality of "arrangements for its withdrawal". Further, it is not obvious why "setting out the arrangements for its withdrawal" should be interpreted as limiting the headline agreement to be reached, as opposed to being directive of core subject matter. It is also far from obvious why "taking account of the framework for its future relationship" should not mean that the content of the agreement should reflect that future framework insofar as that

\footnotetext{
${ }^{10}$ Council Decision, supra note 8, at Explanatory Note. Also as legal requirements for sequencing of negotiations, see European Parliament Resolution of 5 April 2017 on Negotiations With the United Kingdom Following its Notification That it Intends to Withdraw from the European Union, EUR. PARL. Doc. B8 0237, para. 13 (2017) (hereinafter "Parliament Resolution").

${ }^{11} / d$. at paras. 13-15, 28.

${ }^{12}$ Council Decision, supra note 8, at Explanatory Note.
} 
framework has been agreed and in whatever detail it has been agreed. Undoubtedly there might be matters that cannot be concluded within the two-year negotiations, and references to taking account of a future framework accommodates that, however it is unclear why-as per the European Council Decision-Article 50 should direct that the future not be directly negotiable. ${ }^{13}$

The reality is that the European Union itself has wanted various matters of future arrangements to be settled as necessary preliminaries to broader negotiations. This can be seen in particular through the position of EU citizens in the UK, and UK citizens in the EU, and the stress placed on the Irish border issue by the EU in its negotiating position. ${ }^{14}$ If future arrangements for the Irish border can be settled as part of withdrawal arrangements in phase one of the Article 50 process, then is there any principled limit to what future arrangements can be settled under Article 50? If a future issue may be included if it is strictly necessary, ${ }^{15}$ which begs the question: Necessary to whom?

\section{Article 50(3)}

Much has been written about Article 50(3) in terms of whether the process can be halted. That question is not relevant for our purposes: A state's right to secede cannot be compromised simply by having a right to change its mind. The text of the provision is this:

The Treaties shall cease to apply to the State in question from the date of entry into force of the withdrawal agreement or, failing that, two years after the notification referred to in paragraph 2, unless the European Council, in agreement with the Member State concerned, unanimously decides to extend this period.

In one sense, Article 50(3) does create a restriction on the right to leave. A State must wait two years to leave even if it does not wish to negotiate, or even if the European Union does not wish to negotiate. The great British constitutional theorist Dicey pointed out that a power to delay an action was a power to prevent it if "effectiveness (of a measure) depends upon its being passed without delay." ${ }^{16}$ Nevertheless, absent a conscious choice

\footnotetext{
${ }^{13} / d$.

${ }^{14}$ The Irish border issue and the position of citizens' rights are, of course, important to both sides. Their inclusion as an issue requiring resolution as a condition precedent for further negotiations, however, represents a priority placed on it by the European Union.

${ }^{15}$ Council Decision, supra note 8, at Explanatory Note, Annex paras. 10, 14.

${ }^{16}$ Albert Venn Dicey, Introduction to Introduction to the Study of the LAW of the CONSTITUtion xlii (1982).
} 
to operate Article 50 as a trap-as some have argued Article 50 inherently to be ${ }^{17}$-it is difficult to see that the two-year timetable will make the right to leave the EU ineffective.

As will be noted later, this time period protects the European Union from a sudden departure, and from the threat of the same. It also protects both sides, in that they will have time to prepare for life post-exit should no satisfactory Article 50 agreement be reached on the former relationship. Providing both sides can make such preparationswhether jointly through negotiations or by individual preparations for full or partial non-deal scenarios-Article 50(3) is well balanced.

\section{Article 50(4)}

The final provision to take note of is one that states what should be obvious: "For the purposes of paragraphs 2 and 3, the member of the European Council or of the Council representing the withdrawing Member State shall not participate in the discussions of the European Council or Council or in decisions concerning it."

This is logical enough. In the negotiation of the agreement, the withdrawing member state cannot sit on both sides of the negotiation. It cannot be privy to matters of the other side's negotiation strategy. Nor can it vote on whether its own proposals should be accepted.

What should be noted is that Article 50(4) does not stretch to any other European Council decisions other than European Council's decisions as to the final agreement and whether to extend time for negotiations. There is no provision to exclude the withdrawing member state from any European Council discussions other than those referred to Article 52(2) and (3) however little legitimate interest the withdrawing member state might have in the discussions. ${ }^{18}$ The EU's negotiating guidelines take the view that "sincere cooperation"

\footnotetext{
${ }_{17}$ Nick Barber, Tom Hickman \& Jeff King, Pulling the Article 50 'Trigger': Parliament's Indispensable Role, U.K. CONST. L. BLOG (June 27, 2016), https://ukconstitutionallaw.org/2016/06/27/nick-barber-tom-hickman-and-jeffking-pulling-the-article-50-trigger-parliaments-indispensable-role/. For the "trap" label to Article 50, see, e.g., Jonathan Rickford \& Robert Ayling, Brexit Referendum and Article 50 of the Treaty on European Union - A Legal Trap: The Need for Legislation, THE LONDON SCHOOL OF ECONOMICS, (2016), https://www.Ise.ac.uk/collections/law/news/rickfordayling.pdf; Gideon Rachman, Theresa May walks into the Brexit Trap, FINANCIAL TIMES (Oct. 3, 2016), https://www.ft.com/content/7b78f276-8940-11e6-8cb7e7ada1d123b1. See also Horst Eidenmüller, Brexit Negotiation Games, OxFORD Bus. L. BLOG (June 27, 2016), https://www.law.ox.ac.uk/business-law-blog/blog/2016/06/brexit-negotiation-games (The author sums up his view of the Article 50 process seen from just a few days after the referendum result: "Simply put, the rules of the 'exit game' put the UK in a very weak bargaining position").

${ }^{18}$ The European Parliament notes that in respect of such matters, the withdrawing member state is not free to abuse its position. It must comply with the principle of sincere cooperation as regards the consequences of its decisions qua member (i.e. outside the Article 50 context per se), or be excluded from that area of decisionmaking. See Parliament Resolution, supra note 10, at para. 6.
} 
requires the UK "to recognise the need of the 27 Member States to meet and discuss matters related to the situation after the withdrawal of the UK"19

\section{Exclusivity of Article 50}

A final issue is whether Article 50 provides an exclusive process. It is the only process by which an international agreement can be made with a withdrawing member state, a status created by Article 50 itself. Does this mean that Article 50 is a sufficient legal basis for a comprehensive agreement with the withdrawing member state, or is it a mixed agreement requiring member state ratification? The Eur-lex website defines a mixed agreement as follows:

Where its competence is shared with EU countries, the agreement is concluded both by the EU and by the EU countries. It is therefore a mixed agreement to which EU countries must give their consent. The areas in which competences are shared are defined in Article 4 of the Treaty on the Functioning of the EU. (Emphasis in original). ${ }^{20}$

This would potentially make the Article 50 process exclusive only in regards to the few areas of exclusive competence listed in Article 3 of the Treaty on the Function of the EU. The matter is more complicated in that many areas of shared competence have-through EU activity-become matters of exclusive EU competence; ${ }^{21}$ and trade agreements are always agreed as mixed agreements, although their subject matter is overwhelmingly within the Common Commercial Policy. ${ }^{22}$ Nevertheless-unless Article 50 itself is to be read as providing a special competence in respect of such matters-if any part of an agreement falls outside EU competence, then the agreement will be a mixed agreement requiring ratification by all member states and their relevant legislatures. Nonetheless, whilst such a limited reading of Article 50's scope would be in keeping with the ordinary EU approach to making international agreements, it would effectively neutralize the qualified majority provision for an Article 50 agreement. ${ }^{23}$

\footnotetext{
${ }^{19}$ Council Guidelines, supra note 8, at para. 26. See also Steven Peers, Guide to Brexit Negotiations, E.U. L. ANALYSIS (2017) (on what was para. 24 of draft Guidelines).

20 European Union International Agreements and the EU's External Competences, http://eur-lex.europa.eu/legalcontent/EN/TXT/? uri=LEGISSUM:ai0034 (last visited on July 4, 2018).

${ }^{21}$ Dóra Sif Tynes \& Elisabeth Lian Haugsdal, In, Out or In-Between? The UK as a Contracting Party to the Agreement on the European Economic Area, 41 EUR. L.R. 753, 761 (2016).

${ }^{22}$ See, e.g., Opinion 2/15 of the Full Court, [2017] EUECJ Avis-2/15_O.

${ }^{23}$ See Flavier, supra note 3 (addressing the effect of making Article 50 a mixed agreement).
} 


\section{Constitutional Court Decisions}

A review of the literature should start with how Article 50 was addressed by various constitutional courts, as it would be unwise for the provision to be interpreted in ways that challenge the reasoning for why the present state of EU integration is compatible with national constitutions.

There are five constitutional court decisions to note. ${ }^{24}$ Two decisions-Spain and Franceconcern Article 59-or 60, depending on the version-in the abortive European Constitution, which was in all material points like article 50. Three constitutional courts considered Article 50 in the context of the Lisbon Treaty-Germany, Latvia, and, in two decisions, the Czech Republic. The common ground in all of these decisions was that the right to leave upheld state sovereignty or at least made the EU Treaties more like international treaties. The Czech and Latvian Courts considered the Article 50 process in detail, holding that it balanced the sovereign right to leave the EU with protection for the EU against arbitrary disruption through a state's withdrawal.

\section{Spanish Constitutional Tribunal}

The Spanish Constitutional Tribunal considered the equivalent of Article 50 in the European Constitution. Briefly, the Tribunal asserted the importance of the provision in that "sovereignty is always ultimately assured" by the right to leave the EU. ${ }^{25}$ There is no equivalent consideration in respect of the Lisbon Treaty.

Jochen Herbst commented that the Spanish Constitutional Tribunal believed that "the right to leave will have a promoting effect on the European integration process rather than being a contradictory and explosive element." ${ }^{26}$ Such a view suggests that Article 50 needs to be seen as a bona fide attempt to allow those who wish to withdraw to do so, suggesting that the provision should be interpreted at least in an exit-neutral fashion, and certainly not in an exit-hostile manner.

\footnotetext{
${ }^{24}$ In respect of the Lisbon Treaty, there were cases brought in Austria, Belgium, France, Poland, and Slovenia which do not touch on Article 50. See R (on the application of Miller) v. Secretary of State for Exiting the European Union [2017] UKSC 5 (Eng.) (concerning only internal constitutional issues around commencing the process).

25 S.T.C., Dec. 13, 2018 (B.J.C. No. 1/2004) (Spain), https://www.tribunalconstitucional.es/ResolucionesTraducidas/Declaration\%201-2004.pdf (The relevant section is translated in García, supra note 2, at 1002).

${ }^{26}$ Jochen Herbst, Observations on the Right to Withdraw from the European Union: Who are the "Masters of the Treaties?", 6 GERMAN L.J. 1755, 1759-60 (2005).
} 


\section{French Constitutional Court}

The equivalent decision in France considered the withdrawal provision in the European Constitution only to note that "the possibility for signatories to withdraw therefrom, show that said instrument retains the nature of an international treaty." ${ }^{27}$ There was no analysis as to the relationship between the right to withdraw and state sovereignty. This is unsurprising, as the only question was whether the European Constitution meant there needed to be amendments for the French Constitutional basis for membership-Article 88-1 of the French Constitution.

There was no reference to Article 50 in the equivalent case on ratification of the Lisbon Treaty. ${ }^{28}$

\section{German Constitutional Court}

The German Constitutional Court gave the most well-known decision on the national constitutionality of the Treaty of Lisbon. The Lisbon Case developed the Court's earlier Maastricht decision on the effect of Article 20 of the German Constitution-"state sovereignty" - and European integration. ${ }^{29}$

The German Constitutional Court has laid down five areas necessary for State Sovereignty: (1) Control of criminal law; (2) monopoly control of police and military; (3) control of fundamental taxation and expenditure decision; (4) control of basic decisions on social policy; and (5) control of issues of cultural importance. ${ }^{30}$ To these criteria for state sovereignty, the Court also effectively added a sixth criterion: ${ }^{31}$

The right to withdraw underlines the Member States' sovereignty and also shows that the current state of development of the European Union does not transgress the boundary towards a state within the

27 Conseil Constitutionenel [CC] [Counsitutional Court] decision No. 2004-505DC, Nov 19, 2004 (Fr.), http://www.conseil-constitutionnel.fr/conseil-

constitutionnel/root/bank/download/2004505DCen2004_505dc.pdf.

${ }^{28}$ Conseil Constitutionnel [CC] [Constitutional Court] decision No. 2007-560DC, Dec. 20, 2007, Rec. (Fr.) (Treaty amending the Treaty on European Union and the Treaty establishing the European Community).

29 Bundesverfassungsgericht [BVerfG] [Federal Constitutional Court] June 30, 2009, 2 BvE 2/08; Bundesverfassungsgericht [BVerfG] [Federal Constitutional Court] Oct. 12, 1993, BVerfGE 89.

${ }^{30}$ See 2BvE 2/08, supra note 30, at para. 249. See also Elisabetta Lanza, Core of State Sovereignty and Boundaries of European Union's Identity in the Lissabon-Urteil, 11 GERMAN L.J. 399, 406 (2011).

${ }^{31}$ See 2BVE 2/08, supra note 30, at para. 329. 
meaning of international law.... If a Member State can withdraw based on a decision made on its own responsibility, the process of European integration is not irreversible.

There was no discussion of Article 50 beyond that the withdrawal does not require the consent of the EU; if no agreement is reached then membership ceases. ${ }^{32}$

\section{Czech Constitutional Court}

The Czech Constitutional Court heard two challenges to the constitutionality of the Lisbon Treaty. ${ }^{33}$ Unlike with Germany's Lisbon case, the challenges included an attack on Article 50. The judgments have attracted comparatively little interest in comparison to the German decision, perhaps not least because the decision raised no threat of drawing substantive limits to what powers could be transferred to the European Union. ${ }^{34}$

In the 2008 decision we see the familiar contention that Article 50 was an "explicit articulation of ... the continuing sovereignty of Member States," and a re-iteration of the point made by the French Constitutional Court in 2004 that a right to give a notification of withdrawal was a characteristic of international rather than federative treaties. ${ }^{35}$ Referring to this in the 2009 case, the Czech government argued that Article 50 was "an expression of the common will of the Member States to address their future relationships by agreement, consensually, and comprehensively," adding that this was "undoubtedly desirable." ${ }^{\prime 36}$

The Constitution Court rejected arguments that making the right to secede conditional on the observance of Article 50 procedures restricted sovereignty. The thrust of the Court's position was that the nature of the relationship contracted by the member states meant that there needed to be a duty not to just leave overnight, but for a period to make arrangements. To leave without notice would be arbitrary, and the rights gained under the

32 Id. at para. 330.

${ }^{33}$ Nález Ústavního soudu ze dne 26.11.2008 (ÚS) [Decision of the Constitutional Court of Nov. 26, 2008], ÚS 19/08, para. 109 (Czech); Nález Ústavního soudu ze dne 03.11.2000 (Ús) [Decision of the Constitutional Court of Nov. 3, 2009] Pl. ÚS 29/09 (Czech).

${ }^{34}$ See Petr Brisa, The Czech Republic: The Constitutional Court on the Lisbon Treaty Decision of 26 November 2008, 5 EUR. CONST. L.R. 143, 153-54 (2009); and Jiří Přibáň, The Semantics of Constitutional Sovereignty in PostSovereign "New" Europe: A Case Study of the Czech Constitutional Court's Jurisprudence, 13 INT'L J. OF CONST. L. 180 (2015).

${ }^{35}$ See Nález Ústavniho soudu ze dne 26.11.2008, supra note 35, at para. 106.

${ }^{36} / d$. at para. 55. 
Treaties carried with obligations, including to "observe the pre-determined procedures" for withdrawal. The Court considered that Article 50(3)-in providing time for negotiations, and the possibility of extension of that time-was a balance of the interests of the two sides, which did not deny the right to leave. ${ }^{37}$

\section{Latvian Constitutional Court}

The third Constitutional Court to consider Article 50 and its relationship to state sovereignty was that of Latvia, with its decision falling between the two Czech rulings. The approach taken in that case had much in common with the Czech decisions-and, indeed, the Czech Court expressly endorsed the views of their Latvian colleagues. ${ }^{38}$

The Latvian Parliament argued that Article 50 preserved sovereignty by giving member states the last word, and that the requirement to wait two years before a unilateral withdrawal took effect was proportionate by "[t]aking into consideration legal, political, economic, and social bonds that have been formed between the Republic of Latvia and the EU." ${ }^{39}$ If a member state's right to leave of its own volition is subject to a two year delay, the Latvian Parliament argued that this was a necessary function of the relationship that had grown between the state and the EU. The Constitutional Court enlarged on this, holding that the two years was beneficial for the withdrawing member state and the EU as a whole to manage the issues affected by such a withdrawal:

The Constitutional Court indicates that in this context the term of two years is substantial in order to ensure the most lenient possible withdrawal procedure observing the rights and legal interests of the State and its citizens that they could have exercised when in the EU.

Consequently, it is not only favourable but also indispensable to have a term, within which it would be possible to make a compromise regarding those persons who are exercising any of the fundamental freedoms of the $\mathrm{EU}$ at the respective moment, for instance, persons who are legally residing and working

\footnotetext{
${ }^{37}$ See Nález Ústavního soudu ze dne 03.11.2000, supra note 35, at para. 169.

${ }^{38} / d$.

39 Judgment on Behalf of the Republic of Latvia, Case No. 2008-35-01, 15, (April 7, 2009), http://www.satv.tiesa.gov.lv/wp-content/uploads/2008/09/2008-35-01_Spriedums_ENG.pdf (“Latvian Lisbon Case"). This is the official English translation.
} 
in other EU Member States or have concluded an agreement on goods supply or purchase, provision of services, recognition of qualification, functioning of affiliates of an enterprise, as well as exercise other rights on other states of the world that are a party to special agreements with the EU and that would lose these persons in the case of Latvia's withdrawal from the EU. (Emphasis added). ${ }^{40}$

We see the now-post-Brexit referendum-familiar issue of the position of those who will lose the EU law right to continue residing in the present country. The Court recognized that there will be obvious transitional issues of contracts, which would on the stroke of withdrawal be made uneconomic or even illegal due to losing the aegis of European free movement law. ${ }^{41}$ The Court, however, went beyond such narrow, immediate transitional issues to the way that departure risks generally upsetting the way many businesses have operated through affiliates in other member states-for example non-UK fishing companies who operate through UK based subsidiaries and thus qualify as British for the purposes of quotas. ${ }^{42}$ The Court took Article 50 to be a route to generally address the disruption to commerce that withdrawal from the EU may bring - although the question of whether this meant the possibility of permanent arrangements or just transitional ones did not come into clear focus.

\section{Summary of Approach by Constitutional Courts}

The view from the constitutional court literature was very much that Article 50 upheld the rights of member states. The withdrawing member state was not entitled to any deal of its own choosing, and so the extent of the return of powers is as unclear as at the start of the process, ${ }^{43}$ but there is protection for both, in that any rights and obligations between the withdrawing member state and the EU must be agreed by both, although the withdrawing member state may withdraw without an agreement. Save for the issue of withdrawal itself,

\footnotetext{
${ }^{40}$ Latvian Lisbon Case, supra note 39, at 50.

${ }^{41}$ In the last Brexit-or rather Engxit-England withdrew from jurisdiction of the Papacy by way of the Act of Supremacy, Eliz 1, c.1. Specific provision was made for the position of two outstanding appeals to the Pope in matrimonial matters.

42 Despite concerning the future relationship, the European Parliament apparently anticipates such issues being considered in the Article 50 process, see Daniel Boffey, UK Fishermen May Not Win Waters Back After Brexit, EU Memo Reveals, THE GUARDIAN (Feb. 15, 2017, 7:12 AM), https://www.theguardian.com/environment/2017/feb/15/uk-fishermen-may-not-win-waters-back-after-brexiteu-memo-reveals?CMP=twt_gu.

${ }^{43}$ See Nález Ústavního soudu ze dne 03.11.2000, supra note 35, at para. 167.
} 
everything else was open to be dealt with "by agreement, consensually and comprehensively, as the Czech Government submitted in its Lisbon Treaty litigation." ${ }^{44}$

The constitutional courts saw considerable significance in the resolution, removing all doubts as to the right to leave the $\mathrm{EU},{ }^{45}$ and in the provision of an orderly mechanism for withdrawal. The Czech and the Latvian Constitutional Courts went beyond considering the bare fact of the right to leave. Those Courts also considered the detail of Article 50, seeing it as a beneficial provision to facilitate agreeing a resolution to the difficulties arising from departure. There is no sign that these Courts believed they were reading a provision where the only agreement was a narrow divorce agreement for settling bills and ensuring a lack of disruption to EU institutional concerns. Both courts took the view that Article 50 was a beneficial measure-“the most lenient possible," said the Latvian Constitutional Courtthat promoted an orderly exit for those that wanted to leave, as opposed to being a measure to obstruct exit. There is also no sign that anyone involved in the litigation considered the possibility that Article 50 was doubly limited to divorce issues only, and resolving matters of exclusive EU competence. Similarly, there is no sign of considerations as to whether an Article 50 agreement was a mixed agreement, requiring a parallel process for unanimous member state ratification.

What the Czech and Latvian Constitutional Courts identified was that Article 50 does not just create-or clarify-the right to leave the $\mathrm{EU}$, but also creates a process to manage that withdrawal by negotiation, and avoids the possibility of the EU being faced with the damage caused by an immediate secession without the opportunity to discuss future alternatives with the withdrawing member state, or at least make contingency planning when the two years expired.

\section{Pre-Brexit Literature}

It must be admitted that there was comparatively little literature on Article 50 until recently. As Phedon Nicolaides points out-prior to the UK mooting the possibility of renegotiating membership terms-Article 50 did not appear terrible relevant. ${ }^{46}$ For example, the German Law Journal's 2009 Special Section on the Lisbon Case comprised nine articles on the case, and only the briefest mention of Article 50: Christian Wohlfahrt uncritically noted in passing that the Court saw the right to secede-"codified in Article

\footnotetext{
${ }^{44}$ Nález Ústavního soudu ze dne 26.11.2008 (ÚS) [Decision of the Constitutional Court of Nov. 26, 2008] ÚS 19/08 para. 55 (Czech).

${ }^{45}$ For the previous controversy on a right of a member state to unilaterally withdraw from the EU, see HERMANNjoself Blanke \& Stelio Mangiamel, The Treaty on European Union (TEU): A Commentary 1388-1402 (2013).

${ }^{46}$ Phedon Nicolaides, Withdrawal from the European Union: A Typology of Effects, 20 MAASTRICHT J. OF EUR. \& CoMP. L. 209, 210 (2013).
} 
50 "-as evidence of continued sovereignty. ${ }^{47}$ Nevertheless, from the very early considerations of the equivalent provisions in the European Constitution, there appears to have been an assumption that Article 50 negotiations encompassed the entirety of the relationship between the withdrawing member state and the European Union.

\section{Literature on the European Constitution}

Raymond Friel started an article on the equivalent provisions in the European Constitution by describing the process as requiring the parties to "enter into negotiations on a mutually agreeable basis for withdrawal, including a framework for the future relationship between the EU and the Member State." 48 The process itself must be mutually agreed, because, as Friel saw it, the provision was highly unsatisfactory in failing to provide detail as to the procedure. Friel saw Article 50's absence of detail as favoring withdrawing member states, particularly larger ones. It would be possible for a withdrawing member state to refuse to negotiate as a means to getting concessions, whilst still being able to vote in the EU on matters that were not in its legitimate concern, as they would only take effect after departure. ${ }^{49}$ In contrast to recent thinking that the trading relationship was outside the Article 50 process per se, Friel saw the "significance to the EU of the withdrawing member state as a significant trading partner" as being crucial to the negotiations. ${ }^{50}$ The idea that the business of Article 50 was a divorce deal to be agreed without reference to future economic links does not appear to have been considered.

Jochen Herbst noted a considerable weakness of the European Constitution's withdrawal provision - at that point numbered as Article 1-60-in that it assumed "some kind of (legal) relationship will still remain between the Union and the withdrawing Member State even after the withdrawal has come into effect." ${ }^{51}$ The problem that Herbst describes is that the provision-as its essentially identically worded successor in Article 50 of the Lisbon Treaty-assumes that certain business will be taken care of without actually providing a concrete legal basis for taking such decisions. Taken at face value, he argues, the provision appears to prevent the very thing it is designed to achieve by preventing legal consequences flowing from the withdrawal agreement. ${ }^{52}$ If there was no basis under the Article for "interim and grandfathering procedures" then "such an agreement would have

\footnotetext{
${ }^{47}$ Christian Wohlfahrt, The Lisbon Case: A Critical Summary, 10 German L.J. 1277, 1283 (2008).

${ }^{48}$ Raymond Friel, Providing a Constitutional Framework for Withdrawal from the EU: Article 59 of the Draft European Constitution, 53 INT'L COMP. L. Q. 407, 407 (2004).

${ }^{49} / d$. at 426 .

${ }^{50} / d$. at 427.

${ }^{51}$ Herbst, supra note 26, at 1757.

${ }^{52} / d$.
} 
a hard time finding practicable solutions regarding ongoing legal relationships such as cases pending before the ECJ, etc." ${ }^{\prime 53}$ It could be said in reply that it will be the business of the withdrawing member state to give effect to the agreement by including any transitional terms and provisions for ongoing relationships-by definition, EU law should cease to govern such matters in the territory of the now ex-member state. Herbst's objection could be answered similarly as regards to the EU: It has entered into an agreement, and now must use its domestic procedures to carry it into effect. EU legislation is certainly required to give the agreement effect in the European legal order. Nevertheless, the qualified majority to agree the withdrawal agreement might be different from what EU Treaties require for agreements in certain highly relevant areas (e.g. trade deals). This lack of implementation teeth to Article 50 would become a serious issue.

Whilst the issue Herbst raises will work its way into the transformation of Article 50 from exit-friendly to a more exit-hostile approach, his real concern was that bread and butter issues might fall through the cracks. His worry was that "in the absence of a well-drafted withdrawal implementation agreement," issues - such as the position of "the employees of the Union who are nationals of the withdrawing Member State," and whether "the withdrawing Member State is obligated to pay its outstanding contributions," and the fate of "damage claims by individuals based on European law against the withdrawing Member State which were already brought before the ECJ" - might be missed..$^{54}$ This contrasts with many recent assertions that it is only such business that will fall to be agreed.

\section{Literature on Article 50}

Until the morning of June 24, 2016, Article 50 of the Lisbon Treaty was of limited interest in academia. There was not one citation, for example, in Public Law of Article 50 prior to the Brexit referendum, nor in the Law Quarterly Review, nor the Cambridge Law Journal. Even when cited in the context of sovereignty, the provision did not necessarily receive scrutiny.$^{55}$ Article 50 was raised in British literature through the matter of possible Scottish independence, ${ }^{56}$ with at least two articles separately arguing that if Article 50 was the only route for a state to leave the European Union, then it must likewise be the only route by which a part of a state could exit. It is very noticeable when embarking on a literature review of Article 50 that-due to the calls for independence in Scotland and Catalonia-

${ }^{53} / d$.

${ }^{54} / d$.

${ }^{55}$ E.g., Přibáň, supra note 34.

${ }^{56}$ Kenneth Armstrong, An Independent Scotland in the European Union, 3 CAMBRIDGE J. OF INT'L \& COMP. L. 181, 191 (2014); Justin Borg-Bathet, Scottish Statehood and Continued Membership of the European Union: Do we Still Have no Answers?, 19 EDINBURH L. R. 414, 417 (2015); Stephen Tierney, Legal Issues Surrounding the Referendum on Independence for Scotland, 9 EUR. CONST. L. R. 359 (2013). 
the literature on the subject of the European Union and secession from a member state was far livelier than any discussions on Article 50 being invoked directly. ${ }^{57} \mathrm{It}$ is perhaps a sign that it appeared much more likely that a member state would fall apart internally rather than deliberately leave the European Union, and that debate within countries facing internal secessionist issues often emphasized the risk of a loss of European Union membership, drawing academic argument to that issue.

Perhaps the most thorough review of Article 50 is contained in Blanke and Mangiameli's commentary on the Treaty. The Commentary on Article 50 is frequently hostile to Article 50 , for example, siding with the argument that the duty of solidarity between member states should act as a substantive restraint on the right to withdraw. ${ }^{58}$ Nevertheless, it is assumed that the withdrawal agreement will address substantive economic issues:

[W]ithdrawal at a certain level of the MS's economic integration may require maintenance of specific relations between the withdrawing state and the EU. That is why Art. 50 TEU requires that the agreement sets out the arrangements for the withdrawal, taking account of the framework for the State's future relationship with the Union. ${ }^{59}$

Hence, on this view, echoing the approach of the Latvian Parliament in its Lisbon Treaty litigation, ${ }^{60}$ Article 50 allows for a necessary focus on preventing disruption given high levels of economic integration. It is not just about settling accounts.

Phedon Nicolaides took the view that Article 50 negotiations would address the post-exit relationship and its effect on how the withdrawing member state would need to reorganize its affairs. ${ }^{61}$ Nicolaides draws a distinction between terms of withdrawal from the EU and the future relationship between the withdrawing member state and the EU.

57 E.g., Merijn Chamon \& Guillaume Van der Loo, The Temporal Paradox of Regions in the EU Seeking Independence: Contraction and Fragmentation Versus Widening and Deepening?, 20(5) EUR. L. J. 613 (2014); Dimitry Kochenov \& Martijn van den Brink, Secessions from EU Member States: The Imperative of Union's Neutrality, University of Grongin FACULty of LAW ReSEARCh PAPER SeRIES 09/2016 (2016). Carlos Closa, Secession from a Member State and EU Memberships: The View from the Union, 12 EUR. CONST. L. R. 240, 257-60 (2016) (Closa affirms at 259 "this Article provides for an express obligation on the part of the EU to negotiate in the event of an announcement of withdrawal. Ingeniously, Article 50 becomes the general instrument catering for a shrinkage in the scope of application ratione loci of the Union acquis").

\footnotetext{
${ }^{58}$ BLANKE, supra note 45, at 1407.

${ }^{59} / d$.

${ }^{60}$ Latvian Lisbon Case, supra note 39, at 15

${ }^{61}$ Nicolaides, supra note 46.
} 
Having described the existing literature on Article 50 as speculative, he continued by foreshadowing what would become the familiar divorce/future relationship dichotomy. He argues that the heart of the problem with Article 50 was that it provided for both at the same time. ${ }^{62}$ The agreement does not just wind up the business of the withdrawing member state's membership, but assumes that there will still be a relationship between the EU and the withdrawing member state, and that this will be reflected in the agreement.

One of the most extensive considerations of Article 50 was in a 2013 article by Adam Łazowski. He noted the various possibilities for a new relationship in respect of trade, and that difficulties will arise from leaving the Common Agricultural Policy, Common Fisheries Policy, and the Customs Union that might be best addressed by phasing out. ${ }^{63}$ What he says in terms of trade is worth noting for present purposes:

A full-scale divorce from other Member States of the European Union seems to be out of question. As argued at the beginning of this article, a downgrade to a basic free trade area with the European Union might be damaging in many respects-rather, efficient models of integration without membership are something to aim for.

This is precisely the sort of aim, which many now deny as being possible to address within the scope of Article 50.

Łazowski addresses in detail the nature of an Article 50 agreement, concluding that it "is an international agreement between the European Union and a departing country, concluded in accordance with the procedure laid down in Article 218(3) TFEU."64 Writing in 2012, he appeared to assume that Article 50 itself would permit the EU to agree to withdrawal arrangements and giving effect to the future framework-although he briefly speculates that such an agreement may be required if the negotiations go beyond EU treaty making competences. ${ }^{65}$ Writing in 2016-still before the referendum-he noted the existence of a minimalist interpretation of Article 50 restricted to divorce matters, but preferred a second

\footnotetext{
${ }^{62} / d$. at 211.

${ }^{63}$ Adam Łazowski, Withdrawal from the European Union and Alternatives to Membership, 37 (5) EUR. L. R. 523, 532-33 (2012).

${ }^{64} / d$. at 528.

65 Vaughne Millar, Leaving the EU, COMmons LIBRARY RESEARCH PAPER RP13/42 (2013), 11, http://www.parliament.uk/briefing-papers/RP13-42 (hereinafter "Millar II") (citing Lazowski, supra note 63, at 528).
} 
interpretation that would allow for the impact of withdrawal on business to be addressed..$^{66}$ On such a view, the existence of explicit Treaty provisions for reaching types of agreement with third countries-for example the special provisions in respect of international agreements on trade-are neither here nor there. If the matter is one of EU competence, then Article 50 provides a separate basis for entering into agreements with the withdrawing state. ${ }^{67}$ Except insofar as they are referred to in Article 50 itself, specific procedures in reference to third countries are treated as irrelevant to the application of the sole procedure for reaching an international agreement with a current member state. Writing shortly after the referendum, Philip Syrpis took Łazowski to mean that only Treaty amendments lay outside the scope of Article 50, and secondary EU law could be changed by any agreement, a view he adopted. ${ }^{68}$

It is worth noting a European Parliament Briefing paper written by Eva-Maria Poptcheva, albeit one which is caveated as not being an official view: That the Article 50 agreement "should also cover the departing Member State's future relationship with the Union." 69 Poptcheva envisaged that there would be a need for some international agreements to require ratification "by the remaining Member States in accordance with Article 48 TEU," the provision on treaty amendments. ${ }^{70}$ This approach perhaps muddies the waters a little, although for reasons that are entirely understandable. An entity capable of entering into treaties may take a dualist approach. The process for agreeing to something and the process for making that agreement part of its domestic law may be quite different. For example, where any withdrawal agreement requires legal effect in the UK, it will require legislation. There are three difficulties that arise from the European Parliamentary writer's approach. First, the majority required for the Article 50 agreement is that of a qualified majority: The majority for a trade agreement is unanimity, a mismatch which it has been suggested would effectively neutralize Article 50 in respect of relevant issues. ${ }^{71}$ Second, if separate international agreements are necessary to give effect to the withdrawal agreement, then what does that say about Łazowski categorizing the Article 50 agreement

${ }^{66}$ Adam Łazowski, EU Withdrawal: Good for British Business, 22 EUR. PUB. L. 115, 119 (2016).

${ }^{67}$ See discussion supra section B. IV. ("Exclusivity of Article 50 Agreements" as to the interplay between Article 50 as a basis for a withdrawal agreement, and the scope of EU competence).

${ }^{68}$ Philip Syrpis, An Analysis of the EU Law Questions Surrounding Article 50 TEU: Part One, EUTOPIA LAW (2016), https://eutopialaw.com/2016/07/08/what-next-an-analysis-of-the-eu-law-questions-surrounding-article-50-teupart-one/. Łazowski did note that the "potential comprehensiveness" of an Article 50 agreement may lead to a "mixed agreement" if it went beyond EU competence requiring member state ratification, see Łazowski, supra note 63 , at 528. Nevertheless, the point was undeveloped at that stage.

69 Eva-Maria Poptcheva, Article 50 TEU: Withdrawal of a Member State from the EU (2016), http://www.europarl.europa.eu/RegData/etudes/BRIE/2016/577971/EPRS_BRI(2016)577971_EN.pdf.

${ }^{70} / d$. at 4 . There is no mention of "mixed agreements."

${ }^{71}$ See Flavier, supra note 3 (addressing the effect of making Article 50 a mixed agreement). 
as an international agreement for EU law purposes? Third, if withdrawal on agreed terms requires a Treaty amendment, then, other than the right to leave on two years notice, Article 50 will have changed little on the previous position where Treaty amendments were required for orderly withdrawal.

Vaughne Millar produced two House of Commons Briefing Papers on the subject of Article 50. ${ }^{72}$ The first Briefing Paper from 2011 speculates that negotiations would include "revised trade rules with EU Member States and with third parties, changes to the arrangements for the free movement of workers throughout the EU and EEA areas, to name but a few." ${ }^{73}$ She argues that the UK would be likely to seek transitional arrangements pending a final agreement-an early hint at the possibility that the Article 50 agreement might not settle the future relationship, although not for lack of legal basis, but because there is no time. Only towards the end of the 2011 Briefing Paper do we see a hint of what might be the fundamental legal objections to having a withdrawal agreement that addresses the future. She argues that ratification by the remaining member states is required, "for the same reason that accession agreements have to be ratified by all the states concerned before they can enter into force." Millar appears to have in mind the same issue that Adam Łazowski noted: That a withdrawal agreement may require changes to the Treaties in the same way that accession does. Obviously, that is no business of the withdrawing member state, as it represents the EU's post-secession internal governance. Lurking, however, behind this point is the usual principle of EU law, which is that EU agreements cannot create law outside of the EU's competences, a point that Article 50 does not confront. ${ }^{74}$ The EU Treaties set out general and specific procedures for different types of laws and for giving effect to different types of international agreement. Does Article 50 stand as a general power to give legal effect to withdrawal agreements? The question of how EU law accommodates the agreement within its own legal order may have been raised first in the context of primary law-in other words any need to amend the Treaties themselves-but the question as regards secondary EU law waited in the wings.

Millar's second and much longer 2013 Briefing Paper again assumes that the withdrawal agreement may well include the settling of the future relationship-stressing the complexity of the relationships that must be unraveled-citing Sir David Edward that the agreement must address "a highly complex skein of budgetary, legal, political, financial, commercial and personal relationships, liabilities, and obligations." ${ }^{75}$ The Briefing Paper

\footnotetext{
72 Vaughne Millar, In Brief: Leaving the European Union, COMmons LIBRARY STANDARD NOTE SN06089 (2011), http://www.parliament.uk/briefing-papers/SN06089 (hereinafter “Millar I"); Millar II, supra note 65.

${ }^{73}$ Millar I, supra note 72 , at 1.

${ }^{74}$ See Flavier, supra note 3.

${ }^{75}$ Millar II, supra note 65, at 10. The citation from Sir David Edward comes from the Scottish Futures Forum Contribution in 2012.
} 
considers the question of settling the trade relationship with the EU, and at no point suggests a direct legal impediment to this being conducted under the aegis of Article 50. ${ }^{76}$ The only mention of mixed agreements comes in this paper, and is in a citation of Łazowski speculating on the possibility. ${ }^{77}$

A thesis by Toh Pei Roo explicitly takes the view that there is (1) a core element to the withdrawal based on a settling of current positions, including the personal position of those who have relied on their EU law rights to date, and (2) a second element with respect to the future relationship. ${ }^{78}$ Under the head of "[t]he 'divorce' agreement: what does it entail?" are (1) "Post-withdrawal validity of EU provision," (2) "[r]ights and obligations of third parties," (3) "[i]nterim rights of participation in the EU institution," for example the problem that the withdrawing member state is entitled to take part in EU decisions, which are not their legitimate concern as they take effect after the departure, and (4) "[c]urrency-Eurozone considerations." Toh Rei Roo, however, is clear that this is not designed to be an exclusive list of issues to be dealt with and that his paper "does not undermine the significance of other matters which should be addressed in the 'divorce' agreement." He cites Nicolaides and Millar's two Briefing Papers, both of which anticipated a broad agreement. ${ }^{79}$ Earlier in the paper he makes clear the expectation that a trade agreement would be concluded as part of the withdrawal. Having recounted the possibility of EEA or EFTA membership, or bespoke arrangements such as that with Switzerland, Toh Rei Roh argues that the goal of negotiations is for the parties "to maintain their inter-dependent economic cooperation within a formal legal framework." 80

The expectation that trade issues would be addressed in the Article 50 process was found in evidence given to a Parliamentary Committee by Professor Wyatt, one of the UK's most distinguished European lawyers. In 2015-and with the Brexit referendum in sight-the House of Lords European Union Committee produced a report entitled The Process of Withdrawing from the European Union. ${ }^{81}$ The report was largely informed by evidence given by Professor Wyatt and Sir David Edward, both leading legal experts on the European Union, the latter a former judge of the European Union. Strikingly, neither suggested that a trade deal could not be reached as part of the exit process. Professor Wyatt's prediction of

\footnotetext{
${ }^{76} / d$. at 24-31.

77 Id. at 11 , citing Lazowski, supra note 63 , at 528.

78 Toh Pei Roo, Article 50 TEU: Assessing the New Right of Unilateral Withdrawal from the European Union, SCHOOL OF LAW, LEEDS UNIVERSITY 46-55 (2014).

79 Id. at 55 .

${ }^{80} / d$. at $28-29$.

81 european Union Committee, The Process of Withdrawing from the European Union, 2015-16, HL 138 (UK) https://www.publications.parliament.uk/pa/ld201516/Idselect/ldeucom/138/138.pdf.
} 
what would happen in respect of the UK in case of a leave vote was that "the withdrawal agreement and the future relationship agreement were being negotiated in tandem." This was, for Wyatt, "the right process, in terms of legal options, and in terms of aiming for a smooth transition between EU membership and whatever relationship lay beyond." 82 Article 50 is a comprehensive and forward looking process, addressing the practical need to address the immediate issues of withdrawal and what happens afterwards.

Chamon and Van der Loo-addressing the issue of regional secession leading to states leaving the EU-argued that the policy of Article 50 was precisely to reduce the risk of a member state leaving without arrangements to deal with the effects for all concerned. For them, the point was that automatically expelling Scotland if it left the UK, or Catalonia if it left Spain, created precisely the problem that Article 50 was designed to void by creating a process for leaving as opposed to just a right to leave. An unregulated departure would mean "disrupting existing relations within the integrated internal market, without anything to follow up on this rupture." ${ }^{83}$ The importance of the process elements of Article 50 is also found in a European Central Bank paper on Article 50, which took the view that: "Orderly withdrawal [is] presumed to be the aim of the introduction of the exit clause. ${ }^{\prime 84}$ It might be added that to insist that certain issues could not be dealt with in the process is to insist that the withdrawal should be disorderly, albeit with two year's notice to make contingency planning.

This view of Article 50-as a balance of rights and interests between the withdrawing member state and the remaining EU-is found elsewhere in the literature. Frederico Fabbrini argued that Article 50 was a mechanism to "provide solid protections of a member state's rights, while being respectful of the equality of the member states" ${ }^{85} \mathrm{It}$ is a point of view endorsed in a Master's thesis by Guillem Guilet, where he argues that: "Change in the status quo regarding the legal, political, financial, commercial and social relations that take place within the European Union would call for a negotiated solution." ${ }^{86}$

82 The Select Committee on the European Union, Inquiry on The Process of Leaving the European Union, Evidence Session No.1: Supplementary written evidence-Professor Derrick Wyatt QC (PLEO001) (2016), $\mathrm{http}: / /$ data.parliament.uk/writtenevidence/committeeevidence.svc/evidencedocument/european-unioncommittee/the-process-of-leaving-the-eu/written/32079.html.

${ }^{83}$ Chamon, supra note 57 , at 621.

${ }^{84}$ Phoebus Athanassiou, Withdrawal and Expulsion from the EU and EMU: Some Reflections, EUROPEAN CENTRAL Bank Legal Working Papers Series No. 10, 26 (2009).

${ }^{85}$ Frederico Fabbrini, After the OMT Case: The Supremacy of EU Law as the Guarantee of the Equality of the Member States, 16 GERMAN L.J. 1003, 1021 (2015).

${ }^{86}$ Guillem Guimet, State Succession and EU Law: Between 'Internal Enlargement' and Withdrawal, INSTITUTE FOR EUROPEAN STUDiEs (2014),

http://www.academia.edu/15924201/State_Succession_and_EU_Law_between_Internal_Enlargement_and_Wit hdrawal. 
This reflects the position of the Czech and Latvian Courts, that any restraint on the right to leave the European Union at will-in other words the two-year delay-was justified by the benefit to all sides of a procedure that promoted resolution of the various problems flowing from withdrawal to both sides and many private individuals and businesses.

Finally, it is important to note the views expressed by the British government in its information paper for voters during the referendum campaign - when it had no interest in downplaying known or suspected risks. The Government paper showed a shift away from a comprehensive view of Article 50 found in most of the earlier literature, but nevertheless saw the dividing lines as unclear. Article 50, it was contended, "does not specify how much the withdrawal agreement itself should say about the future relationship," but "any sort of detailed relationship" would be a separate agreement. ${ }^{87}$ The view taken was that it is "unclear from the terms of Article 50 how far the arrangements for the UK's future relationship with the EU would be included in a withdrawal agreement." 88 The government was unclear as to whether such an agreement can be reached alongside the Article 50 agreement or not-seeing it as a matter of negotiation not a matter of law. ${ }^{89}$ The paper was clear that the EU must agree to a trade agreement unanimously, ${ }^{90}$ even if it was often unclear on the exact reasons why.

Interestingly from our perspective, the UK government paper, addressed the question of the UK's trade position with third countries. It saw no legal objection to entering into negotiations or even making agreements with such countries, only a very practical problem that such countries will want to know what comes out of the Article 50 negotiation..$^{91}$ It would make no sense to negotiate in detail with a party, which might stay in the Customs Union. The paper anticipated that the UK's relationship with those with whom the EU presently has free trade agreements could be addressed as a preliminary issue in negotiations. ${ }^{92}$

87 Secretary of State for Foreign and Commonwealth Affairs, The Process for Withdrawing from the European UNION, 2016, Cm. 9216, at para. 2.15 (UK).

${ }^{88}$ Id. at para. 3.6.

${ }^{89}$ Id. at para. 2.15 .

90 Id. at paras. $3.6-3.8$.

${ }^{91} / d$. at para. 2.8 .

92 Id. at para. 4.8. In the context of WTO quotas, the EU and the UK have been negotiating common positions, see Hans Van Der Burchard, US Rounds on Britain Over Food Quotas as Post-Brexit Trade Woes Deepen, PoLITICO, (Oct. 4, 2017), https://www.politico.eu/article/us-rounds-on-britain-over-food-quotas-as-post-brexit-trade-woesdeepen/. 


\section{E. The Post-Brexit Referendum Approach}

Łazowski-writing shortly after the Brexit referendum-argued that "[t]here are many reasons why a withdrawal agreement should cover both the terms and conditions of exit and future relations," but added "[s]adly, this is not where the current debate is heading." 93

This section considers three ways in which the interpretation of Article 50 has diverged, often radically, from pre-referendum readings. Changes in understanding of an untested legal provision may have many explanations. It is possible for interpretations to change simply because it had never been necessary to look closely at a provision, or earlier interpretations had previously failed to consider its full context. It may simply be that different people were now interpreting the provision. It may be that the referendum result made different interpretations more attractive; ${ }^{44}$ or that before the referendum there was a different bias towards reading it as an open door for member states to leave, with the lack of departures as proof of commitment to the European Union. ${ }^{95}$

It is not the purpose of this article to determine the true meaning. It may be that the concept of true meaning is futile. As one leading British political commentator said in respect of the practical effects of Article 50: "[It] offers an open field for interpretations because it is an unworkable mess." 96 That the very interpretation of Article 50 has become so uncertain means that Article 50 risks failing in a basic requirement of law: To give the weaker party the protection of identifiable rules. ${ }^{97}$ Article 50 may well be one of provisions which demonstrates the sense of Oliver Wendall Holmes's celebrated aphorism that the law is just "prophecies of what the courts will do in fact." ${ }^{18}$ What interests this paper is, first, the fact of a change of direction: If Article 50 is an unworkable mess, then its

93 Adam Łazowski, Procedural Steps Towards Brexit, CEPS COMMENTARY (July 13, 2016), https://www.ceps.eu/publications/procedural-steps-towards-brexit.

${ }^{94}$ An early post-referendum move towards a narrower interpretation of Article 50 begins, "I am still trying to process the shock of the UK referendum, which has dealt a historic blow to the European Union ... ", see Stefano Micossi, A Fresh Start for the European Unity after Brexit, CEPS COMMENTARY (June 29, 2016), https://www.ceps.eu/publications/fresh-start-european-union-after-brexit.

95 Essentially, the view of Herbst, supra note 26, at 1759-60, and the Spanish Constitutional Court, see DECLARACIÓN 1/2004, supra note 25.

96 Matthew Parris, MPs and the EU can together derail Brexit, THE TIMES (Oct. 28, 2017), https://www.thetimes.co.uk/article/mps-and-the-eu-can-together-derail-brexit-krqt6rml0.

97 LON L. Fuller, The Morality of LAW 33-39 (rev. ed. 1969). See also, Adrian Vermeule, Veil of Ignorance Rules in Constitutional Law, 111 YALE L .J. 399, 419 (2001) (that constitutional protections will not give reliable protection if so uncertain in meaning that they placed those behind the protections in the hands of the interpreter).

98 Oliver Wendall Holmes, The Path of the Law, 10 HARV. L. R. 457, 461 (1897). 
suggested meanings are falling in a very different place than before the referendum. Second, that the change has been generally unfavorable to the position of a withdrawing member state. Third, that this suggests that Article 50's heart is not as much on the side of state sovereignty as was often previously thought. It does not matter for these purposes if the more recent interpretations are the right interpretations. The point is that choices were open to be made, and the direction in which they are being taken.

There are essentially three areas to be explored in this section: (I) Agreement of future relationship; (II) restrictions on withdrawing member state preparations; and (III) extent of continuing financial obligations.

\section{Agreement of Future Relationship}

Immediately after the Brexit referendum, the EU Trade Commissioner, Cecilia Malmstrom, argued that a trade agreement was impossible until the UK became a third-country upon leaving the EU: "First you exit then you negotiate." ${ }^{\prime 99}$ Stefano Micossi robustly argued that Article 50 only required withdrawal arrangements, and there was no necessary link to the future relationships, quoting Article 50(2) and highlighting the words "take account" as if they made what followed purely optional. ${ }^{100}$ Writing soon after the referendum-in August 2016-Hugo Flavier and Sébastien Platon noted that was "common assumption" that there were two sorts of agreement required: A "divorce agreement" and a "future arrangement." ${ }^{101}$ On this view, Article 50 provides a legal basis for a "divorce agreement" and-at best-a non-enforceable "future framework" - which, as set out earlier, is the view taken by the EU in its agreed negotiating position. ${ }^{102}$ This is now crystallized in the European Council's view that the future is not even for negotiation, Article 50 permits at the most an "identification of an understanding over the framework for the future relationship" as a precondition for any transitional arrangements. ${ }^{103}$

Responding to the development of this line of reasoning, Łazowski noted that there were three approaches. First, as the pre-referendum literature suggested, Article 50 was a free-standing provision for entering agreements. Second, that there were limitations in Article 50's scope, which required parallel negotiations of an international agreement between the withdrawing member state and the EU under ordinary treaty making

\footnotetext{
${ }^{99}$ Urban, supra note 4.

100 Micossi, supra note 94.

${ }^{101}$ Flavier, supra note 3.

${ }^{102}$ Council Decision, supra note 8, at Explanatory Note.

${ }^{103} / d$.
} 
powers. ${ }^{104}$ Third, and in Łazowski view the worst option, is the one proposed by Donald Tusk within a week of the referendum result: That the settling of future issues had to be left until after exit-with complex transitional arrangements being the only alternative to Article 50 and the Treaties requiring a period of "no deal," and such arrangements would be "profoundly complicated and prone to litigation."105

The comprehensive view of Article 50 has, however, retreated greatly. The undeniable weak point in that view was the distinction between what Article 50(2) says should be set out-withdrawal arrangements-and taken into account-“framework . . . for future relationship". This weakness has been opened up into a divorce/future chasm, bridgeable by transitional arrangements. The withdrawal agreement ceases to be a means to directly address the most fundamental consequence of a member state withdrawing, in other words that much of the relationship between the withdrawing member state and the rest of the EU-and the world-will disappear. As we saw in the constitutional court literature, the Czech government had lauded Article 50 as "an expression of the common will of the Member States to address their future relationships by agreement, consensually, and comprehensively." 106

What has been reached is a mixture of often overlapping concepts as to:

(a) Whether it is possible to make definitive agreements-or even negotiate-as regards the future within the Article 50 process, beyond an awareness of a future framework to be taken into account. ${ }^{107}$

(b) What areas of law and policy can or cannot be addressed under Article 50. Flavier and Platon say that it is arguable "that the ordinary rules of competences apply in respect of what areas of law and policy can be addressed in agreements reached by the EU under that provisions, ${ }^{108}$ although on this view the citizens' rights issue would fall out of Article 50 as third-country immigration issues are almost entirely outside EU competence. ${ }^{109}$

\footnotetext{
${ }^{104}$ Łazowski, supra note 93 , at 3-5.

${ }^{105} / d$. at $4-5$.

${ }^{106}$ Nález Ústavního soudu ze dne 26.11.2008 (ÚS) [Decision of the Constitutional Court of Nov. 26, 2008] ÚS 19/08 para. 55 (Czech).

${ }^{107}$ Council Decision, supra note 8, at Explanatory Note; Micossi, supra note 94.

${ }^{108}$ Flavier, supra note 3.

${ }^{109}$ Piet Eeckhout \& Eleni Frantziou, Brexit and Article 50 TEU: A Constitutionalist Reading (UCL European Institute, Working Paper No. 25, 2016).
} 
Others see the legislative limits of Article 50 as being primarily an inability to amend primary EU law, in other words, the Treaties themselves. ${ }^{110}$

(c) Whether certain issues, although governing the future-for example the Irish border issue-or which fall outside the EU's competence-for example rights of those who will become third country nationals in EU member states, or vice versa-are nevertheless strictly necessary for the withdrawal agreement and so fall under Article $50 .{ }^{111}$

(d) The sequencing of reaching agreements under Article 50, whereby the European Union relies on the provision to justify requiring that certain issues must be resolved first. ${ }^{112}$

(e) What must be left to agreement under the ordinary international agreement rules of the Treaty on the Functioning of the European Unity? As those provisions apply to agreements with third countries, the withdrawing member state would need to be a third country before such agreements could be reached. ${ }^{113}$

(f) Insofar as Article 50 could not be used to agree for the future, could the resultant difficulties be mitigated through transitional arrangements? ${ }^{114}$ Otherwise, Article 50 would guarantee that "legal, political, economic, and social bonds" would come to a disorderly cliff-edge resolution that the Latvian and Czech Constitutional Courts thought it was designed to prevent. ${ }^{115}$ It should be noted that doubts have been raised as to whether transitional agreements are permissible under Article 50. ${ }^{116}$

The EU's interpretation of Article 50's scope-which was considered earlier when discussing the text of Article 50-is a synthesis of these ideas. ${ }^{117}$ The future, in principle, cannot be definitively agreed upon or directly negotiated, but transitional arrangements are possible, and require an identification of an understanding of the future framework. ${ }^{118}$ The issues seen by the EU as necessary for orderly withdrawal are dealt with first - the

\footnotetext{
110 Poptcheva, supra note 69, at 4; Syrpis, supra note 68.

${ }^{111}$ Council Decision, supra note 8, at Explanatory Note, Annex paras. 10, 14.

112 Parliament Resolution, supra note 10, at paras. 13-15.

113 Łazowski, supra note 93 , at 4-5.

114 Parliament Resolution, supra note 10, at para. 14.

115 Latvian Lisbon Case, supra note 39, at 15. See also Nález Ústavního soudu ze dne 26.11.2008 (ÚS) [Decision of the Constitutional Court of Nov. 26, 2008] ÚS 19/08, para. 55 (Czech).

${ }^{116}$ See Peers, supra note 19 ; Łazowski, supra note 93 , at 4-5.

${ }^{117}$ See supra notes 8-13 and accompanying text.

${ }^{118}$ Council Decision, supra note 8, at Explanatory Note; Parliament Resolution, supra note 10, at para. 14.
} 
divorce/future divide in what can be definitively agreed upon under Article 50 is reflected in the order of business. ${ }^{119}$ This ordering of discussions is itself reflected in the expected nature of the transitional arrangements, which are "bridges towards the foreseeable framework for the future relationship" (emphasis added), underlining that no final agreements are to be reached as regards future relationship.

\section{Cannot Negotiate with Rest of the World}

It has passed into conventional wisdom that a withdrawing member state cannot legally conduct trade negotiations with other countries whilst still a member of the EU. This is unequivocally asserted in the European Parliament's resolution, ${ }^{120}$ although the European Council Guidelines do not address the issues. ${ }^{121}$ The point appears to be accepted by the British Government. ${ }^{122}$ This point contrasts with the position taken in the UK Government's paper on the Article 50 process published during the referendum campaign, which highlighted only the practical problem of negotiating with countries who could not be sure of what the UK could agree until after its trade discussions with the EU were concluded. ${ }^{123}$

The argument is essentially as follows. The common commercial policy is an area of exclusive competence for the EU under Article 3 TFEU. The effect of exclusive competence is defined in Article 2 TFEU: "When the Treaties confer on the Union exclusive competence in a specific area, only the Union may legislate and adopt legally binding acts, the Member States being able to do so themselves only if so empowered by the Union or for the implementation of Union acts."

As the competence to negotiate trade treaties is only enjoyed by the $\mathrm{EU}$ and not the member states, as long as the withdrawing member state is still a member state it cannot negotiate trade treaties.

There are four fundamental objections to this. First, it is far from obvious why this should restrict the member state in terms of negotiation-Article 2 TFEU refers to legislation and the adoption of legally binding acts. Second, it is far from obvious how the exclusive competence over the common commercial policy can extend to periods where the common commercial policy will not apply. Member states can exercise treaty-making

\footnotetext{
${ }^{119}$ Parliament Resolution, supra note 10, at para. 15.

${ }^{120} / d$. at para. 6.

${ }^{121}$ Peers, supra note 19, at para. 24. With respect to what became para. 26 of the final Council Guidelines, see supra note 8.

122 Department for International Trade, Preparing for our Future UK Trade Policy, 2017, Cm. 9470, at 27-28 (UK).

${ }^{123}$ Id. at para. 3.6.
} 
powers in respect of fields of exclusive EU competence if the subject matter falls beyond the geographical reach of EU law-for example where non-metropolitan territories are outside the EU. ${ }^{124}$ It is difficult to see why the same should not apply where treaties will take effect beyond the temporal limits of EU competence. Third, if the argument is correct, then the withdrawing member state is forbidden generally from legislating on any matter where the existing law would be covered by matters of exclusive EU competence. Yet no one would sensibly deny a member state the right to pass new laws to replace EU laws immediately upon withdrawal. Fourth, if we are to go down the route that exclusive EU competence ousts the ability of Member States to legislate or negotiate with respect to a post-exit scenario, then why should this not equally apply where the Member State has lost the competence to act under the occupied field theory? ${ }^{125}$

It has been useful in this case to consider the counterarguments in some length as they show how broad the limitations on the withdrawing member state would be if the logic of the trade restriction were taken to its logical conclusion. To deny the withdrawing member state the ability to make legislative provision for the disapplication of EU law would be obviously nonsensical, and Poptcheva notes a consensus on that point. ${ }^{126}$

As a side-point, an issue arises as to the extraction of the UK from mixed agreements. ${ }^{127}$ Here, the UK is a party as a sovereign state, but only by reason of it being part of the EU. ${ }^{128}$ The EU has apparently been happy for the UK having an independent role in extracting the UK from such agreements, even where-as with the WTO-the EU has exclusive competence. ${ }^{129}$ If withdrawing member states are excluded from negotiating Common Commercial Policy matters in preparation for withdrawal, this seems anomalousalthough immensely practical to prevent the UK losing the benefit of the EU's position and the EU being left with a disproportionate burden.

\footnotetext{
124 Paliatha Kohona, Some Notable Developments in the Practice of the UN Secretary-General as Depositary of Multilateral Treaties: Reservations and Declaration, 99 AM. J. OF INT'L L. 433, 446-47 (2005) (relating to the Fish Stocks agreement under UN Convention on the Law of the Sea, which fell under exclusive EU competence). The geographical limits of that competence meant that member states with non-EU territories could ratify the treaty with effect limited to those geographical areas.

125 The occupied field theory is that "a national measure ceases to be justified whenever the Community has already adopted rules designed to protect the matters mentioned therein," see Katharina Eikenberg, Article 296 (ex 223) E.C. and External Trade in Strategic Goods, 25 EUR. L.R. 117, 122 (2000).

126 Poptcheva, supra note 69, at 1.

127 See Adam Lazowski \& Ramses A. Wessel, The External Dimension of Withdrawal from the European Union, UNIVERSITY OF WESTMINSTER, (2017), https://www.utwente.nl/en/bms/pa/research/wessel/wessel122.pdf.

${ }^{128}$ See also Tynes \& Haugsdal, supra note 21 , at $762-65$.

129 Lazowski \& Wessel, supra note 127, at 5. With regards to the EU and the UK co-operating on this issue currently governed by the Common Commercial Policy, see Burchard, supra note 92.
} 


\section{Subsisting Legal Obligations}

A controversy has arisen as to what may be described as the divorce settlement-how much does the UK owe to the EU? The EU's position is currently found in its Essential Principles on Financial Settlement. ${ }^{130}$ It is unnecessary here to consider the merits of legal arguments, whether framed in terms of European or international law. Post-referendum, the matter has been considered at length by the House of Lords European Union Committee, which recounts the arguments in both directions. ${ }^{131}$ Pre-referendum, the UK Government's information paper on Article 50 spelt out many challenges that would be faced following a leave vote, but made no mention of what is now commonly known as the Brexit Bill. ${ }^{132}$

It may assist to set out a summary of potential liabilities calculated on a gross basis: ${ }^{133}$

\begin{tabular}{|l|l|l|}
\hline Commitment/liability for & $\begin{array}{l}\text { UK share (adjusted for } \\
\text { rebate) (€bn) }\end{array}$ & $\begin{array}{l}\text { UK share (non-adjusted) } \\
\text { (€bn) }\end{array}$ \\
\hline $\begin{array}{l}\text { 1. Reste à Liquider } \\
\text { (outstanding } \\
\text { commitments) to end 2018 }\end{array}$ & 29.9 & 39.1 \\
\hline $\begin{array}{l}\text { 2. Significant legal } \\
\text { commitments to end 2018 }\end{array}$ & 17.9 & 23.3 \\
\hline 3. Budget for 2019-20 & 21.9 & 28.6 \\
\hline $\begin{array}{l}\text { 4. EU borrowing-accrued } \\
\text { liability as at end-2018 }\end{array}$ & 6.3 & 8.3 \\
\hline $\begin{array}{l}\text { 5. Pension (accrued liability as } \\
\text { at end 2018) }\end{array}$ & 7.7 & 10.0 \\
\hline $\begin{array}{l}\text { 6. Contingent liabilities (as at } \\
\text { end 2018) }\end{array}$ & 3.3 & 4.3 \\
\hline Total & 86.9 & 13.7 \\
\hline
\end{tabular}

The size of the possible payment needs underlining. The gross non-rebated figure is $€ 113.7 \mathrm{bn}$-currently about $£ 100 \mathrm{~m}$-allowing for no deductions in terms of assets. The

130 Tf50 (2017) 2/2 - Commission to UK, Essential Principles on Financial Settlement (June 12, 2017), https://ec.europa.eu/commission/sites/beta-political/files/essential-principles-financial_settlement_en_1.pdf (hereinafter "EU Financial Position").

${ }^{131}$ See European Union Committee, Brexit AND the EU Budget, 2016-17, HL 125, ๆๆ 98-137 (UK).

${ }^{132} \mathrm{Cm}$. 9216, supra note 87.

133 Zsolt Darvas, Konstantinos Efstathiou \& Ines Gonclaves Raposo, Divorce Settlement or Leaving the Club? A Breakdown of the Brexit Bill (Breugel Working Paper No. 3, 2017). 
actual net contribution of the UK for $2016 / 17$ is $f 8.1 \mathrm{bn} .{ }^{134}$ The claim would thus be for over twelve years of current net contributions. Even if the UK did give the EU f350m per week, this would represent just under five-and-a-half years of current annual contributions-almost a complete budget cycle.

The Breugel Working Paper from, which the above table was taken, nevertheless suggested "the Brexit bill is by far the least important economic issue in the EU27-UK negotiations." 135 Herbst was concerned that the issue of outstanding contributions might be overlooked, ${ }^{136}$ but the real issue that has come into focus post-referendum is not outstanding contributions, but how far future contributions survive an Article 50 process whose default position in Article 50(3) is that "the Treaties... cease to apply" to the withdrawing member state. It is difficult to see that the issue would have been overlooked in the pre-referendum literature if liabilities on the scale suggested by Breugel had been anticipated. Millar's analysis, for example, of the implications of withdrawal included a section on "EU budget contributions," but gives no suggestion that liabilities would necessarily continue post withdrawal. ${ }^{137}$

At the time of this Article, it is important to note that the methodology for the Brexit-bill remains to be settled. It is particularly unclear how the Reste à Liquider claim-the largest single part of the EU's claims, as shown by the table above-will be resolved. The EU's Essential Principles on Financial Settlement provides no detail on why, and how far, the UK should be liable with respect to the Reste à Liquider, merely an assertion that they should be met. ${ }^{138}$ The UK government may have produced an analysis to break down the various heads of claim into its component parts, but it is unpublished, and all we know is that it took three hours to present and flabbergasted EU opposite numbers. ${ }^{139}$ The issues raised above may disappear. The issues may be resolved on a basis-which is unclear-or claims may be substantiated and accepted. But at the moment, financial settlement issues have gained greatly in significance post-referendum.

\footnotetext{
${ }^{134}$ Matthew Keep, The UK's Contribution to the EU's Budget, House of Commons LIBRARY BRIEFIng Paper, (Oct. 9, 2017), http://researchbriefings.files.parliament.uk/documents/CBP-7886/CBP-7886.pdf.

${ }^{135}$ Darvas, supra note 133, at 4.

${ }^{136}$ Herbst, supra note 26, at 1757 (as to the risk of outstanding contributions being overlooked in negotiations).

${ }^{137}$ Millar II, supra note 65 , at 36-38.

${ }^{138}$ EU Financial Position, supra note 130.

139 Peter Foster, James Rothwell \& Gordon Rayner, Brexit showdown: EU Left 'Flabbergasted' After British Negotiators Dismantle Legal Basis for Divorce Bill, THE TelegRAPH, (Aug. 30, 2017, 10:30 PM), http://www.telegraph.co.uk/news/2017/08/30/brexit-showdown-eu-left-flabbergasted-british-negotiatorsdismantle/.
} 


\section{F. Discussion}

At the start of the article three propositions were set out. First, the understanding of the requirements of Article 50 had shifted greatly after the referendum. Second, this shift had been unfavorable to the withdrawing member state. Third, this shift had created tensions with the idea of member state sovereignty. The first two propositions will be considered briefly, as they should be clear from a consideration of the literature review and the section on post-referendum contentions. The third proposition is more theoretical, and is admittedly more difficult, and requires greater elaboration.

\section{First Proposition}

With respect to the first proposition, a comparison between the pre-Brexit referendum literature review and post-referendum contentions on the Article 50 process are striking. Pre-referendum, there is only a little sign in that literature of questions of mixed agreements might de facto neutralize the Article 50 process, as Flavier and Platon put it. ${ }^{140}$ There are hints at what was to come, for example, Vaughne Millar expressly assuming that ratification by the member states would be required, with any further implications to the subject matter of Article 50 going unexplored. ${ }^{141}$ Nor had there been doubts that the different business heads of divorce and future relationship could be dealt with together. The awkwardness in Article 50 was in how to accommodate the two in a single process. ${ }^{142}$ The issues around financial settlement were not foreshadowed. Herbst's concerns in 2005-that matters of settling accounts might be overlooked-was true of the subsequent pre-referendum literature, if wide of the mark in terms of the actual Article 50 negotiations. ${ }^{143}$ The two years allowed under Article 50 between the notification of withdrawal and actually leaving the EU was time for both sides to negotiate and prepare, ${ }^{144}$ and there was no sign that issues of exclusive EU competence would impede the power of the withdrawing member state to prepare for its withdrawal by discussing trade deals with third countries.

\footnotetext{
${ }^{140}$ Flavier, supra note 3.

${ }^{141}$ Millar I, supra note 72, at 2. See also Poptcheva, supra 69, at 4

142 Nicolaides, supra note 46 , at 211

${ }^{143}$ Herbst, supra note 26, at 1757.

${ }^{144}$ Latvian Lisbon Case, supra note 39, at 50; Nález Ústavního soudu ze dne 26.11.2008 (ÚS) [Decision of the Constitutional Court of Nov. 26, 2008] ÚS 19/08 para. 55 (Czech).
} 


\section{Second Proposition}

With regard to some of the changes set out above, the disadvantage to the withdrawing member state of the new readings is fairly obvious. (1) Finalizing any aspect of the future relationship is impossible. Łazowski suggested that unfinished arrangements are "half-baked." ${ }^{145}$ Such a pejorative description will not always be accurate. Both parties might prefer to take time on issues because of their importance, or put back issues lacking in importance. The withdrawing member state might well not wish to replace EU membership with a single monolithic Article 50 agreement, but on the dominant post-referendum readings, Article 50 closes off the possibility of any definitive arrangements being settled. (2) Sequencing of negotiations to place what the EU sees as divorce issues can serve to prioritize matters of EU institutional interest. ${ }^{146}(3)$ The use of transitional arrangements may be "prone to litigation." ${ }^{147}$ (4) Insofar as the time-limited element of Article 50 can be operated as a trap by the $\mathrm{EU}$, weakening the position of the withdrawing member state who is most in need of an agreement as time ticks down. ${ }^{148}$ Time limited transitional arrangements would allow the trap to be set a second time. ${ }^{149}$ (5) Withdrawing member states cannot even start negotiating trade arrangements with third countries. (6) Article 50 requires a strong qualified majority for ratification viewed post-referendum as a mixed agreement; Article 50 requires unanimity.

Issues of the so-called Brexit Bill require more consideration. The EU's claim is for "commitments and liabilities," 150 suggesting that the UK will pay nothing more than would have been the case had it remained a member. If there is nothing more than that, then there is no disadvantage in still paying after withdrawing. But rhetorically powerful maxims such as "EU taxpayers should not pay at 27 for obligations undertaken by 28 " may gloss considerable subtleties deserving analysis. ${ }^{151}$ There ought not to be any controversy as to

\footnotetext{
${ }^{145}$ Eleni Frentziou \& Adam Łazowski, Brexit Transitional Period: The Solution is Article 50, CEPS COMmENTARY (Sept. 9, 2017), https://www.ceps.eu/publications/brexit-transitional-period-solution-article-50. See also Syrpis, supra note 68.

${ }^{146}$ For the relationship between Article 50 and sequencing, see Parliament Resolution, supra note 10, at paras. 13-15. The list of issues identified as "strictly necessary" for Brexit negotiations have been identified by the EU. It is obvious that the EU would prioritize the effects on itself above that of the withdrawing member state; the point raised here is that Article 50 itself has been read as requiring this sequencing.

${ }^{147}$ Łazowski, supra note 93 , at 4 .

148 See supra note 17 , and accompanying text.

149 Daniel Finkelstein, The Best We Can Do on Brexit is Play for Time, THE TIMES (Oct. 17, 2017, 12:01 AM), https://www.thetimes.co.uk/article/we-need-to-play-for-time-on-brexit-gh5xktcnb.

${ }^{150}$ EU Financial Position, supra note 130.

151 James Rothwell, James Crisp \& Peter Foster, Michel Barnier Accuses Britain of 'Nostalgia' for Benefits of EU Membership in Frosty Press Conference, THE Telegraph (Aug. 31, 2017, 12:52 PM),
} 
the withdrawing member state meeting its share of the EU's equivalent of a national debt as of the date of departure-points 4,5 and 6 in the table, above. It is not so much that the payments were approved during the state's membership, ${ }^{152}$ but these liabilities accrued during membership, even though liability to pay-often contingent-would not have fallen due until later. The staff pensions, for example, are deferred pay for work done whilst the UK was a member. To deny them is to treat the legal personality of the EU as a corporate veil to hide behind, ${ }^{153}$ and not to engage with the substance of member state responsibilities for the EU.

But there are scenarios where liability can be seen as serving as a penalty or a deterrent. A Breugel Working Paper highlights that it is unclear whether the UK should be given credit for payments that would never have gone to the EU-in other words the rebate ${ }^{154}$-or whether the payment should be on a gross or net basis-in other words should a deduction be made for amounts that the EU would have paid back to the UK as regional aid etc. ${ }^{155}$-and whether a single payment should be made, or installments, or payments made as relevant EU liabilities fall due. ${ }^{156}$ The EU position appears to anticipate gross payments, but the UK can recover the financial position by remaining in the EU programs for as long as it takes for the UK's commitments to that part of the Reste à Liquider to be fulfilled. ${ }^{157}$ It is currently unclear whether commitments include payments that the EU could choose to halt. Nor is any obvious account taken where the future commitment represents expenditure for which the EU and only the EU will directly benefit, nor where the EU gains a directly equivalent asset for the amount committed. Nor is it clear if the EU's corporate veil is to be lifted for the purposes of recognizing member state responsibility for EU liabilities, but not for the purpose of an interest in assets. ${ }^{158}$ With

http://www.telegraph.co.uk/news/2017/08/31/brexit-bulldog-david-davis-hold-frosty-press-conference-euchief/.

152 The UK voted only once (in 2016) for the budget during the present budget cycle, see Darvas, supra note 133, at 7.

${ }^{153}$ What this means is, the equivalent of shareholders being able to say that the debts of the company belong to the legal person of the company and not themselves. An attempt by the UK to deny responsibility for accrued liabilities would be using the legal personality of the EU and not itself.

154 Id. at 43-44, para. 4 (2017). Ironically, such an approach would take the same position on the amount of EU contributions as on the notorious "We send the EU f350 million a week" slogan by "Vote Leave" in referendum campaign.

${ }^{155} / d$. at para. 5.

$156 / d$. at para. 6.

157 See EU Financial Position, supra note 130, at 2 (stating, "the UK should continue to benefit from all programmes as before the withdrawal until their closure under the condition that it respects the applicable Union legal rules").

${ }^{158}$ Darvas, supra note 133 , at 4-5. 
regard to the contributions for the remainder of the 2014-20 budget cycle, this head of potential claim directly suggests that liabilities under the Multiannual Financial Framework Regulation would survive a member state's departure from the EU. This would, absent a transitional agreement, lead to a withdrawing member state being liable for budget payments even though the quid pro quo advantages would have ceased.

If Brexit were rationalized as a breach of contract, such an approach for damages would be seen as penal by most western legal systems. Although the precise nature of the rule against contractual penalties varies between countries, most systems would strike down a contractual clause that sought to impose damages without a reasonable link to loss, ${ }^{159}$ and the EU's loss cannot be based on a gross figure for the withdrawing member state's contributions. It must always be based on net contributions after allowing for any rebate. ${ }^{160}$ Otherwise it is like a seller claiming for the recommended retail price of a ring when the buyer defaults, notwithstanding the seller retaining the ring and agreeing to sell at a discount. At the time of this Article, it remains the case that the financial settlement may include claims whose contractual equivalent provisions would be normally seen as penal rather than compensatory.

Further, at time of this Article, we do not know if this is the end of the so-called Brexit Bill. Catherine Barnard argued immediately after the referendum that there will be a neverending list of liabilities that the withdrawing member state must meet. What of third parties who lose economically from the cessation of EU law rights, such as loss of access to UK fishing waters? ${ }^{161}$ There may be further turns, which are still largely unforeseen.

\section{The Third Proposition}

The third proposition is that the shift in interpretation undermines Article 50 as upholding member state sovereignty. This can appear counterintuitive. Article 50 provides an explicit right for member states to leave the EU, and for the decision to do so to be reached under their own national constitutions. The German Constitutional Court showed that "the process of European integration is not irreversible." ${ }^{162}$ The argument here is that creating

${ }^{159}$ Cavendish Square Holding BV v Talal El Makdessi [2016] UKSC 67 para. 37 (UK), where the UK Supreme Court saw it as a rule "derived from Roman law by Pothier, Traité des Obligations, No 346," which is to be found in France (CODE CIVIL [C. CIV.][CIVIL CODE] art. 1152 (Fr.)); Germany (BÜRGeRLICHES GeSETZBUCH [BGB][CIVIL CODE], §§ 343, 348, (Ger.)); Switzerland (OBLIGATIONENRECHT [OR][CODE OF OBLIGATIONS] Mar. 30, 1911, art. 163.3 (Switz.)), Belgium (CODE CIVIL [C.CIV.] art. 1231 (Belg.)); and Italy (Art. 1384 C.c (It.))."

160 It might be queried whether VAT receipts, being counted as the EU's "own resources," should be seen as member state contributions per se. Arguably, they are the EU's own tax base, for which each member state acts only as tax collector. Alternatively, this is just a means by which each member state contributions. It is, however, beyond this article to chase through all scenarios.

${ }^{161}$ Catherine Barnard, The Practicalities of Leaving the EU, 41 EUR. L.R. 484, 485 (2016).

${ }^{162}$ Bundesverfassungsgericht [BVerfG] [Federal Constitutional Court] June 30, 2009, 2 BvE 2/08, para. 329. 
reversibility does not preclude the possibility that the provision creates "a hostile rather than friendly environment for withdrawal." 163 If such an environment is created, then the provision's role in supporting state sovereignty is diminished. As we saw in the literature review on constitutional court cases, both the Czech and Latvian Constitutional Court-in considering Article 50 in sovereignty-based challenges-looked beyond the headline and right into how they saw it operating in practice. ${ }^{164}$

The argument here draws heavily on the approach of the Canadian Supreme Court in the Quebec Secession Case, where the Court held that values of federalism, democracy, the rule of law, and protection for minorities place a duty on both sides of secession negotiations to engage with the concerns of each other. ${ }^{165}$ There are two legitimate majorities in any democratic secession-in other words the would-be departing territory and the rest of the polity-and "[t]here can be no suggestion that either of these majorities 'trumps' the other." 166 In the Canadian context, these values meant that a would be secessionist state had to negotiate all matters of interest with the rest of Canadabeing itself a legitimate democracy-and could only leave under the constitution. But federalism and democracy meant that the majority for secession in the relevant state would equally require engagement by the rest of Canada with Quebec-also being a legitimate majority-with its concerns, including secession. It is an approach in keeping with the Czech government's view in the Lisbon Case litigation of Article 50 as creating a comprehensive and consensual approach. ${ }^{167}$

Although the Quebec Secession Case was in the context of a sovereign state and constitutional arrangements without a positive right to secede, the comparison is nevertheless valid. First, that case was based on constitutional values-federalism, rule of law, democracy, and protection of minorities - which translate directly into the EU context. As Matej Avbelj concluded, despite the absence of sovereign statehood, "European integration meets the criteria of a constitutional form of a union." 168 Da Baere and Ross see the EU as occupying an intermediate constitutional ground in terms of mutual duties. The relationship between the EU and its member states is one, which goes beyond international law good faith, although falling short of federal-constitutional-fidelity,

\footnotetext{
${ }^{163}$ Smismans, supra note 1.

${ }^{164}$ See supra notes 33-40, and accompanying text.

165 Reference re Secession of Quebec, [1998] 2 S.C.R. 217, paras. 90-95, (Can.).

166 Id. at para. 93.

${ }^{167}$ Nález Ústavního soudu ze dne 26.11.2008 (ÚS) [Decision of the Constitutional Court of Nov. 26, 2008] ÚS 19/08 (Czech). See also Chamon, supra note 57, at 621.

${ }^{168}$ Matej Avbelj, Theory of European Union, 36 EUR. L. R. 818, 835 (2011).
} 
using the German constitution as a comparator. ${ }^{169}$ Canada, however, has a more confederal structure. Unlike, for example, Spain, there is no Canadian concept of indissolubility leading to the conclusion that no local majority is legitimate on matters of self-determination. ${ }^{170}$ Thomas Verellen considered at length the similarities in constitutional values and structures, concluding that, despite differences, Canada and the EU adhere to "a constitutional principle of federalism understood as the pursuit of equal autonomy between both orders of government that together constitute a compound polity." ${ }^{171}$ Chamon and Van der Loo saw the Quebec Secession Case as being of general application in terms of self-determination in European democracies. If correct, their conclusion ought to apply to the EU itself, unless the value of self-determination does not apply to the EU itself, despite being ostensibly recognized by Article 50 for the purpose of recognizing member state continuing sovereignty. ${ }^{172}$

Second, whilst Article 50 makes secession a non-negotiable fixed point, this need not-as the Canadian Supreme Court feared-remove the duty of the seceding state to engage with the rest of the polity. ${ }^{173}$ It should not be thought that because on one issue-albeit the principal leave/remain issue-the views of the seceding state are paramount, then the values underlying the decision must be irrelevant to every other issue, and that the other party gains the right to treat its views as trumps on all other points. The values of democracy and federalism would still inform the duty to negotiate on both sides, even if Canada from day one accepted a Quebec vote to leave. Instead, the better view of the dynamic of the Canadian Supreme Court's reasoning is that the price for recognizing Quebec's right to secede was that it could not dictate terms, which, once recognized meant "[b]oth sides would then have to negotiate on the act and terms of secession." ${ }^{174}$ The values of democracy and federalism would still inform the duty to negotiate on both sides, even if Canada accepted a Quebec vote to leave.

The Canadian approach is that respect for the democratic decision in the secessionist state means that its concerns must be on the table no less than those of the rest of Canada. The approach in recent interpretations of Article 50 is that, having recognized the fundamental

\footnotetext{
${ }^{169}$ Geert De Baere \& Timothy Ross, EU Loyalty as Good Faith, 64 INT'L CoMP. L. Q. 829, 874 (2015).

${ }^{170}$ See Jure Vidmar, The Concept of the State and Its Right of Existence, 4 CAMBRIDGE J. OF INT'L \& COMP. L. 547, 564 (2015) (as to the contrast between the Spanish and Canadian approaches). See also Chamon, supra note 57, at 616 (as to "federal loyalty" in the Belgian constitution forbidding unilateral secession).

171 Thomas Verellen, Federalism and Foreign Affairs in Canada and the European Union: The Search for Equal Autonomy, 5 CAMBRIDGE J. OF INT'L \& COMP. L. 306, 312 (2016).

${ }^{172}$ Chamon, supra note 57 , at 616.

${ }^{173}$ Reference re Secession of Quebec, [1998] 2 S.C.R. 217, paras. 93-95, (Can.).

${ }^{174}$ Chamon, supra note 57 , at 616.
} 
sovereign right of withdrawal from the $\mathrm{EU}$, the process thereafter prioritizes the interests of the EU by viewing orderly withdrawal primarily from the perspective of the EU. Budgetary implications to the EU must be addressed for an orderly withdrawal, the exclusion of the UK from international air travel is apparently not. ${ }^{175}$ It cannot, of course, be suggested that the EU has a duty to ensure that the withdrawing member state is in the best of all positions on its day of departure. It is rather that each side-in negotiationsmust engage with the issues that withdrawal creates for both of them. Insofar as sovereignty has been pooled in a manner compatible with continuing sovereignty, each will have lent to the other for mutual gain. Both sides must be treated as having benefited, and both sides should recognize the difficulties with removing the withdrawing state's share off the pooled sovereignty creates for the other. The withdrawing member state is taking something back after having benefitted from pooling, and the EU is giving back something having benefited from the loan. ${ }^{176}$ Identification of what is strictly necessary for withdrawal cannot be viewed from the perspective of the EU alone-as appears to be the case with the list for priority sequencing set out by the European Council. ${ }^{177}$ The post-referendum approach to Article 50 has no such balance. Indeed, as seen with the restriction on third country trade negotiations, this inequality is compounded in that the withdrawing member state may be prohibited from arranging an orderly withdrawal with respect to third country relationships.

The obvious counterargument is that it is the withdrawing state leaving the Union, not vice versa, so counteracting the side effects of withdrawal is the business of the withdrawing member state, not the EU. ${ }^{178}$ But, more importantly, this is to mistake (a) the interests of the remaining EU member states in the context of withdrawal negotiations with, (b) the constitutional interests of the member states in recognizing a right to withdraw as an expression of state sovereignty. In setting a constitutional rule for a future hypothetical, the member states should have approached the issue on the basis of a veil of ignorancein other words not knowing which side of the rule they would be on. ${ }^{179}$ Rules of a

175 James Crisp, Ryanair Boss: 'No Flights' Between UK and EU After Brexit, The TelegRAPH (July 11, 2017, 6:24 PM), http://www.telegraph.co.uk/news/2017/07/11/ryanair-chief-michael-oleary-discuss-brexit-effect-aviation/. See also supra note 14 , and accompanying text.

${ }^{176}$ On pooled sovereignty, see Andras Jaka, Neutralizing the Sovereignty Question: Compromise Strategies in Constitutional Argumentation Before European Integration and Since, 37 EUR. CONST. L.R. 375, 393 (2006). See also Nález Ústavního soudu ze dne 26.11.2008 (ÚS) [Decision of the Constitutional Court of Nov. 26, 2008] ÚS 19/08 paras. 104-06 (Czech); Nález Ústavního soudu ze dne 03.11.2000 (Ús) [Decision of the Constitutional Court of Nov. 3, 2009] PI. ÚS 29/09 para. 147 (Czech).

177 Council Decision, supra note 8, at Explanatory Note; Council Guidelines, supra note 8, at para. 5.

${ }^{178}$ E.g., Kevin Doyle, We Won't Help the UK Come up With Border Solution, INDEPENDENT (July 28, 2017, 2:59 PM), https://www.independent.ie/business/brexit/we-wont-help-the-uk-come-up-with-border-solution-leo-varadkar35977592.html.

${ }^{179}$ Vermeule, supra note 97 , at 399. For the origin of this approach, see JOHN RAWLS, A THEORY OF JUSTICE 118-23 (2d ed. 1999). It is also-from a republican rather than a liberal perspective-the same point recently made in respect 
moderate character will be gained if the member states understand that they do not know if they will be on the wrong end of hostile or unfair rules-nor would MEPs in their role know whether their country would be on the wrong end of unfair rules. In Article 50, such rules should not undermine the EU - as the states making the rules might be on that side of any withdrawal-but nor can they be hostile to a state exercising the sovereign choice to withdraw. A rule of unanimity in approving withdrawal agreements is perfectly understandable on this basis. A rule that quantified the leaving member state's share of accrued liabilities would be acceptable to any reasonable member state who hypothesized that would be on either side of the process. And, obviously, a reasonable person is taken to accept a rule that favors the innocent over the guilty, and would accept a sanction if they offended. But for a state to accept rules that deny a withdrawing member state the opportunity to reach future arrangements, restrict their capacity to make replacement arrangements, require future payments on a gross basis, and sequences negotiations to prioritize the EU's concerns, those steps can only be agreed if withdrawing from the EU is accepted as an offense against membership. But if Article 50 takes that view, then it views withdrawing from the EU not simply in terms of a return of sovereignty that had been given on loan -in other words the pooled sovereignty model ${ }^{180}$ - but as the member state violating its obligations. If, however, the Union is one of sovereign states, and this is part of the fundamental identity of the $\mathrm{EU}$, then requiring the return of sovereignty is no wrong to the EU. The possibility of separation is part of the process of coming together, which was essentially the Spanish Constitutional Tribunal's view of Article 50's predecessor. ${ }^{181}$

In short, if the second proposition is correct, and the new readings of Article 50 materially disadvantage the withdrawing member state, then the provision does not truly accept the concept of member state sovereignty. It accepts the headline right to leave, but otherwise does not respect the exercise of the right. The strong symbolic content of Article 50 is distinctly tarnished. ${ }^{182}$ The divergence from the Canadian approach is striking.

\footnotetext{
of "equal concern and respect" for those addressed by a law. See David Yuratich, Article 13(2) TEU: Institutional Balance, Sincere Co-Operation, and Non-Domination During Lawmaking?, 18 GERMAN L.J. 99, 107 (2017) (only applied as between member states rather than citizens). Unless the act of withdrawing from the EU itself manifests a lack of equal concern and respect on the part of the withdrawing member state, its concerns in the process should be hypothesized by the law as being equal to that of the remaining part of the EU.

${ }^{180}$ See supra note 176 , and accompanying text.

181 See DeCLARACIÓN 1/2004, supra note 25 ("the right to leave will have a promoting effect on the European integration process").

${ }^{182}$ Garcia, supra note 2, at 1020.
} 


\section{G. Conclusion}

What this article should have demonstrated is that the rules of the Article 50 process are of a highly uncertain meaning. The uncertainty is shown by the swing in readings of the requirements of the Article. Article 50 has gone from being criticized as a procedural blank sheet, ${ }^{183}$ to having considerable intricacy read in. The possibility of agreeing to the future has been taken off the table, requirements as to the sequence of negotiations have been read in, and time limited transitional arrangements as a bridge to understandings of a yet to be negotiated future framework have become a key feature.

When the process of Brexit is finished-assuming it is carried through-it will be interesting to identify the ultimate view taken of the requirements of the Article 50 process, and the obligations and limitations placed on the withdrawing member state. At the time of writing, the readings taken appear consistently to disadvantage the withdrawing member state, and that the EU's Treaties approach the question of withdrawal in a spirit that is the precise reverse of that which would be taken if a state wished to secede from Canada. In Canada, the secessionist state has no positive right to leave, but its interests are to be placed on the negotiation table in full and equal to those of the federation. ${ }^{184}$ In the EU, there is a right to leave, but the withdrawing member state's interests in discussing the future are diminished, and its interests generally are treated as having a lower priority in sequencing. ${ }^{185}$ The EU has been very clear that it sees itself not using superior bargaining power, but acting according to the legal requirements of Article 50. By being able to attribute its negotiating approach to requirements of lawwhether its reading is the better view or not-the EU has been able to forestall what the Canadian Supreme Court saw as the sanction for any party that refuses to negotiate: A loss of legitimacy. ${ }^{186}$

Should any member state ever consider withdrawing in the future, the process of Article 50 would doubtless be a significant issue in the debate. To the ordinary vicissitudes of seceding where there are asymmetries in bargaining power, ${ }^{187}$ will be added the risks of a process that creates a hostile environment for the withdrawing member state. ${ }^{188}$ The extent to which Article 50 upholds member state sovereignty is thus diminished.

\footnotetext{
${ }^{183}$ Friel, supra note 48 , at 426.

${ }^{184}$ Reference re Secession of Quebec, [1998] 2 S.C.R. 217, paras. 90-95, (Can.).

${ }^{185}$ See supra notes 8-12, and accompanying text.

${ }^{186} / d$. at para 95.

${ }^{187}$ Tridimas, supra note 7, at 313.

${ }^{188}$ Smismans, supra note 1.
} 